\title{
Turkish national consensus on breast cancer management during temporary state of emergency due to COVID-19 outbreak
}

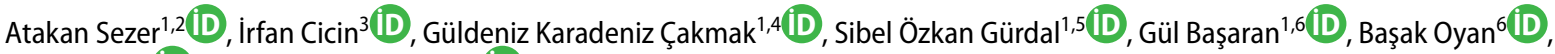 \\ Yeşim Eralp ${ }^{6}$ (D), Bahadır M. Güllüoğlu ${ }^{1,7}$ (iD with Turkish National Breast Oncology Specialists Task Force for COVID-198 \\ 1 SENATURK Senology Academy-Turkey, Istanbul, Turkey \\ ${ }^{2}$ Department of General Surgery, Trakya University School of Medicine, Edirne, Turkey \\ ${ }^{3}$ Department of Medical Oncology, Trakya University School of Medicine, Edirne, Turkey \\ ${ }^{4}$ Department of General Surgery, Bulent Ecevit University School of Medicine, Zonguldak, Turkey \\ ${ }^{5}$ Department of General Surgery, Namik Kemal University School of Medicine, Tekirdag, Turkey \\ ${ }^{6}$ Department of Medical Oncology, MAA Acibadem University School of Medicine, Istanbul, Turkey \\ ${ }^{7}$ Department of General Surgery, Marmara University School of Medicine, Istanbul, Turkey \\ ${ }^{8}$ Turkish National Breast Oncology Specialists Task Force for COVID-19 consists of Müfide Nuran Akçay, Erol Aksaz, Kemal Atahan, Semih Baskan, \\ Betül Bozkurt, Neslihan Cabioğlu, N. Zafer Cantürk, Hasan Şenol Coşkun, Murat Çalıkapan, Bülent Çitgez, Orhan Demircan, Lütfi Doğan, Mustafa Emiroğlu, \\ Özlem Er, Serap Erel, Ali İlker Filiz, Ertuğrul Gazioğlu, Sadullah Girgin, Sema Sezgin Göksu, Semih Görgülü, Mehmet Ali Gülçelik, Semra Günay, Günay \\ Gürleyik, Veysel Haksöyler, Abdullah Ĭğci, Hasan Karanlık, Abut Kebudi, Saadettin Kılıçkap, Belma Koçer, Hande Köksal, Fatih Köse, Bekir Kuru, Semra Paydaş, \\ Ayfer Kamalı Polat, Serdar Özbaş, Necati Özen, Vahit Özmen, Gürhan Sakman, Aykut Soyder, Özlem Sönmez, Mehmet Ali Nahit Şendur, Cemalettin Topuzlu, \\ M. Ümit Uğurlu, Hilal Ünal, Levent Yeniay, Cem Yılmaz, Idris Yücel.
}

\section{ABSTRACT}

Objective: Cancer care is excessively influenced by the COVID-19 outbreak for various reasons. One of the major concerns is the tendency for delayed surgical treatment of breast cancer patients. The outbreak has urged clinicians to find alternative treatments until surgery is deemed to be feasible and safe. Here in this paper, we report the results of a consensus procedure which aimed to provide an expert opinion-led guideline for breast cancer management during the COVID-19 outbreak in Turkey.

Material and Methods: We used the Delphi method with a 9-scale Likert scale on two rounds of voting from 51 experienced surgeons and medical oncologists who had the necessary skills and experience in breast cancer management. Voting was done electronically in which a questionnaireformatted form was used.

Results: Overall, 46 statements on 28 different case scenarios were voted. In the first round, 37 statements reached a consensus as either endorsement or rejection, nine were put into voting in the second round since they did not reach the necessary decision threshold. At the end of two rounds, for 14 cases scenarios, a statement was endorsed as a recommendation for each. Thirty-two statements for the remaining 14 were rejected.

Conclusion: There was a general consensus for administering neoadjuvant systemic therapy in patients with node-negative, small-size triple negative, HER2-positive and luminal A-like tumors until conditions are improved for due surgical treatment. Panelists also reached a consensus to extend the systemic treatment for patients with HER2-positive and luminal B-like tumors who had clinical complete response after neoadjuvant systemic therapy.

Keywords: COVID-19, breast cancer, breast surgery, consensus

Cite this article as: Sezer A, Cicin I, Karadeniz Çakmak G, Özkan Gürdal S, Başaran G, Oyan B, et al. Turkish national consensus on breast cancer management during tempo rary state of emergency due to COVID-19 outbreak. Turk J Surg 2020; 36 (2): 147-163

\section{Corresponding Author}

Atakan Sezer

E-mail: atakansezer@hotmail.com

Received: 24.04 .2020

Accepted: 29.04 .2020

Available Online Date: 06.05.2020

( Copyright 2020 by Turkish Surgical Society Available online at www.turkjsurg.com

DOI: $10.5578 /$ turkjsurg.4815

\section{INTRODUCTION}

We are going through an exceptional period in which the Coronavirus Disease-2019 (COVID-19) outbreak has dramatically affected all aspects of human life worldwide including Turkey (1). As the number of COVID-19 cases is increasing, its burden on health care system becomes more demanding. In many parts of the world, routine health care for non-COVID 19 disorders are either being restricted or interrupted due to COVID-19 patient overload (2). Daily practice involving surgical treatment is also influenced by this unprecedented situation as well. Recently, many surgical societies have released statements recommending that elective surgeries other than those for cancer should be cancelled or postponed due to current restrictions on standard health care provision $(3,4)$. However, none of these recommendations provide guidance for circumstances in which surgery would not be feasible even in the context of cancer treatment. Operation room schedules for cancer patients 
are becoming more tightened as the demand for specific care of COVID-19 patients is increasing. With the escalation of the outbreak, surgical wards are also increasingly being reserved for COVID-19 patients when necessary. Therefore, imbalanced bed allocations for those patients further decreases the chance of timely surgery (5-7). Another concern is the likelihood of viral transmission even during day-case procedures in cancer who have a high risk for COVID-19-related mortality due to impaired immune function $(8,9)$.

Management of breast cancer $(\mathrm{BC})$ patients whose surgery is inadvertently delayed due to the restrictions is also an ongoing matter of uncertainty $(10,11)$. Valid alternatives include starting or extending systemic treatments comprising of chemotherapy (CT), endocrine treatment (ET) and/or HER2-blokade with or without radiotherapy (RT). Nevertheless, CT may predispose patients to severe infection or contribute to the higher mortality risk in patients who have already acquired COVID-19 during their treatment course $(12,13)$. Thus, due to the aforementioned factors, current COVID-19 outbreak may potentially influence the outcome of BC patients by jeopardizing standard practice. Therefore, $B C$ specialists urgently need a guideline on how to manage those $B C$ patients in whom surgery is deferred until the outbreak subsides.

Categorically, there are two groups of BC patients anticipated to be managed separately under the current pandemic circumstances: those who are already eligible for up-front surgery and those who recently completed their neoadjuvant systemic treatment (NST) and are waiting to be scheduled for surgery as their next step of treatment.

In order to provide guidance for BC specialists in routine daily practice for $B C$ management during outbreaks such as COVID-19, we designed a consensus procedure with the Delphi method. The consensus design consists of statements on different case scenarios provided to panel members for their voting on a 9-point Likert scale. In all cases, patients were assumed to be otherwise healthy, COVID-19-free, physically fit and without any comorbidity that may interfere with the treatment. We asked the panelists to vote for their preferred management among the given options considering that a surgical approach is not a suitable option until the outbreak subsides.

\section{MATERIAL and METHODS}

Delphi method with Likert scale was used for the current consensus procedure (14). Consensus development committee (CDC) consisted of four breast surgeons (AS, GKC, SOG, BMG) and four medical oncologists (IC, GB, BOU, YE). As the first step, CDC generated the statements, decided the voting system, number of rounds, turn-around time for each round, quorum requirement, voting score thresholds for endorsement and rejection as well as panelist nomination criteria.
Nine-point Likert scale was used for each voting: selecting 1, 2, 3 meant "I disagree", 7, 8, 9"I agree" and 4, 5, 6 "abstained" for each statement (Supplement). If the panel could not reach a consensus on any statement at the first round, a second round of voting was held. For each round, the panelists were given 72 hours to return their voting results. "Quorum" was regarded to be attained if overall voting (attendance) rate for any statement was minimum 51\%. As decision thresholds, "endorsed as a recommendation" was regarded if minimum $75 \%$ of the panelists voted for " $1,2,3$ : agree", whereas "rejected as a recommendation" was regarded if minimum $25 \%$ of the panelists voted for "7, 8, 9: disagree".

For any decision to be reached, voting on statements had to pass through 2 steps. First, quorum had to be attained and second, at least one of the endorsement or rejection thresholds had to be crossed at any of the rounds. If voting on a statement did not attain the quorum or pass the threshold for any of decision, the result was regarded as "consensus not reached"for that particular statement. If the quorum was attained but votes did not cross the thresholds, then a second round of voting was held for that particular statement. During the second round, the same requirements for decision was sought. If any of the decision thresholds was attained at any round, consensus procedure was regarded to be completed for that particular statement. On the other hand, if any decision was not reached for a particular statement at the end of the second round, the result was regarded as "consensus not reached" accordingly.

Requirements of being a member of the consensus panel for voting included: having at least 10 years of BC surgical or oncological treatment experience, dealing with $\mathrm{BC}$ patients during minimum $\% 50$ of his/her daily clinic time, working at a tertiary reference hospital with comprehensive BC treatment facilities for minimum 5 years and attending regular multidisciplinary tumor boards at least every week for minimum 5 years. All correspondences with the panelists were done by e-mail.

No statistical analysis was used. Results of each voting at rounds were given as descriptive variable $(n=\%)$.

\section{RESULTS}

Totally, 46 statements on 28 different case scenarios were drafted and sent to the panelists for voting. Seventy-six physicians were nominated as panelists according to the eligibility criteria. Forty-eight of them were breast surgeons and 28 were medical oncologists. Informed consent was obtained from all individual panelists.

The first round of voting started on March $25^{\text {th }}, 2020$ and finished on March $27^{\text {th }}, 2020$. At this round, fifty-one panelists returned with their voting, and therefore, the quorum (67\%) was attained. Of those who voted, 40 were breast surgeons and 11 were medical oncologists. According to the voting results of the first round, five statements were endorsed as recommendation for 5 case 
SUPPLEMENT. National Consensus on Breast Cancer Management During Temporary State of Emergency Due to COVID-19 Outbreak in Turkey

Condition: In patients who are physically fit and without any co-morbidity, under exceptional circumstances like the COVID-19 outbreak in which routine surgical management of breast cancer is suspended for a temporary period of time.

Abbreviations (HR: Hormone receptor, NST: Neoadjuvant systemic treatment, RT: Radiation treatment)

Definition (Relevant regimen: Single or combined systemic treatments previously recommended for similar subgroup of patients in neoadjuvant and/or adjuvant settings)

\section{In newly admitted patients with invasive breast cancer diagnosis:}

1. Under exceptional circumstances like the COVID-19 outbreak in which routine surgical management is unlikely; For a new premenopausal patient with stage T1NOMO, grade 3, triple negative (HER2-negative/HR-negative) tumor, giving NST (4-6 months) with any relevant regimen is suitable.

$\begin{array}{ccccccccc}1 & 2 & 3 & 4 & 5 & 6 & 7 & 8 & 9 \\ \text { Strongly Disagree } & & & & & & & & \text { Strongly agree }\end{array}$

Comment: Comment (if applicable, please state your preferred regimen):

2. Under exceptional circumstances like the COVID-19 outbreak in which routine surgical management is unlikely; For a new postmenopausal patient with stage T1NOM0, grade 3, triple negative (HER2-negative/HR-negative) tumor, giving NST (4-6 months) with any relevant regimen is suitable.

$\begin{array}{ccccccccc}1 & 2 & 3 & 4 & 5 & 6 & 7 & 8 & 9 \\ \text { Strongly Disagree } & & & & & & & & \text { Strongly agree }\end{array}$

Comment: Comment (if applicable, please state your preferred regimen):

3. Under exceptional circumstances like the COVID-19 outbreak in which routine surgical management is unlikely; For a new premenopausal patient with stage T1NOM0, grade 3, HER2-positive/HR-negative tumor, giving NST (4-6 months) with any relevant regimen is suitable.

$\begin{array}{ccccccccc}1 & 2 & 3 & 4 & 5 & 6 & 7 & 8 & 9 \\ \text { Strongly Disagree } & & & & & & & & \text { Strongly agree }\end{array}$

Comment: Comment (if applicable, please state your preferred regimen):

4. Under exceptional circumstances like the COVID-19 outbreak in which routine surgical management is unlikely; For a new postmenopausal patient with stage T1NOMO, grade 3, HER2-positive/HR-negative tumor, giving NST (4-6 months) with any relevant regimen is suitable.

$\begin{array}{ccccccccc}1 & 2 & 3 & 4 & 5 & 6 & 7 & 8 & 9 \\ \text { Strongly Disagree } & & & & & & & & \text { Strongly agree }\end{array}$

Comment: Comment (if applicable, please state your preferred regimen):

5. Under exceptional circumstances like the COVID-19 outbreak in which routine surgical management is unlikely; For a new premenopausal patient with stage T1NOM0, grade 3, HER2-positive/HR-positive tumor, giving NST (4-6 months) with any relevant regimen is suitable.

$\begin{array}{ccccccccc}1 & 2 & 3 & 4 & 5 & 6 & 7 & 8 & 9 \\ \text { Strongly Disagree } & & & & & & & & \text { Strongly agree }\end{array}$

Comment: Comment (if applicable, please state your preferred regimen):

6. Under exceptional circumstances like the COVID-19 outbreak in which routine surgical management is unlikely; For a new postmenopausal patient with stage T1NOMO, grade 3, HER2-positive/HR-positive tumor, giving NST (4-6 months) with any relevant regimen is suitable.

$\begin{array}{ccccccccc}1 & 2 & 3 & 4 & 5 & 6 & 7 & 8 & 9 \\ \text { Strongly Disagree } & & & & & & & & \text { Strongly agree }\end{array}$

Comment: Comment (if applicable, please state your preferred regimen):

7. Under exceptional circumstances like the COVID-19 outbreak in which routine surgical management is unlikely; For a new premenopausal patient with stage T1NOM0, grade 1, luminal A-like (HER2-negative/HR-highly positive/Ki67 < 15\%) tumor, giving neoadjuvant endocrine treatment alone (4-6 months) with any relevant regimen is suitable.

$\begin{array}{ccccccccc}1 & 2 & 3 & 4 & 5 & 6 & 7 & 8 & 9 \\ \text { Strongly Disagree } & & & & & & & & \end{array}$


SUPPLEMENT. National Consensus on Breast Cancer Management During Temporary State of Emergency Due to COVID-19 Outbreak in Turkey (continue)

8. Under exceptional circumstances like the COVID-19 outbreak in which routine surgical management is unlikely; For a new postmenopausal patient with stage T1NOMO, grade 1, luminal A-like (HER2-negative/HR-highly positive/Ki67 < 15\%) tumor, giving neoadjuvant endocrine treatment alone (4-6 months) with any relevant regimen is suitable.

$\begin{array}{ccccccccc}1 & 2 & 3 & 4 & 5 & 6 & 7 & 8 & 9 \\ \text { Strongly Disagree } & & & & & & & & \end{array}$

9. Under exceptional circumstances like the COVID-19 outbreak in which routine surgical management is unlikely; For a new premenopausal patient with stage T1-2N1M0, grade 2, luminal A-like (HER2-negative/HR-highly positive/Ki67 < 15\%) tumor, giving neoadjuvant endocrine treatment alone (4-6 months) with any relevant regimen is suitable.

$\begin{array}{ccccccccc}1 & 2 & 3 & 4 & 5 & 6 & 7 & 8 & 9 \\ \text { Strongly Disagree } & & & & & & & & \text { Strongly agree }\end{array}$

Comment:

10. Under exceptional circumstances like the COVID-19 outbreak in which routine surgical management is unlikely; For a new postmenopausal patient with stage T1-2N1M0, grade 2, luminal A-like (HER2-negative/HR-highly positive/Ki67 < 15\%) tumor, giving neoadjuvant endocrine treatment alone (4-6 months) with any relevant regimen is suitable.

$\begin{array}{ccccccccc}1 & 2 & 3 & 4 & 5 & 6 & 7 & 8 & 9 \\ \text { Strongly Disagree } & & & & & & & & \text { Strongly agree }\end{array}$

Comment:

11. Under exceptional circumstances like the COVID-19 outbreak in which routine surgical management is unlikely; For a new premenopausal patient with stage T1N0M0, grade 2, luminal B-like (HER2-negative/HR-low positive/Ki67 > 15\%) tumor, giving neoadjuvant endocrine treatment alone (4-6 months) with any relevant regimen is suitable.

$\begin{array}{ccccccccc}1 & 2 & 3 & 4 & 5 & 6 & 7 & 8 & 9 \\ \text { Strongly Disagree } & & & & & & & & \end{array}$

Comment:

12. Under exceptional circumstances like the COVID-19 outbreak in which routine surgical management is unlikely; For a new premenopausal patient with stage T1N0M0, grade 2, luminal B-like (HER2-negative/HR-low positive/Ki67 > 15\%) tumor, giving neoadjuvant chemotherapy alone (4-6 months) with any relevant regimen is suitable.

$\begin{array}{ccccccccc}1 & 2 & 3 & 4 & 5 & 6 & 7 & 8 & 9 \\ \text { Strongly Disagree } & & & & & & & & \text { Strongly agree }\end{array}$

Comment: Comment (if applicable, please state your preferred regimen):

13. Under exceptional circumstances like the COVID-19 outbreak in which routine surgical management is unlikely; For a new postmenopausal patient with stage T1NOMO, grade 2, luminal B-like (HER2-negative/HR-low positive/Ki67 > 15\%) tumor, giving neoadjuvant endocrine treatment alone (4-6 months) with any relevant regimen is suitable.

$\begin{array}{ccccccccc}1 & 2 & 3 & 4 & 5 & 6 & 7 & 8 & 9 \\ \text { Strongly Disagree } & & & & & & & & \text { Strongly agree }\end{array}$

Comment: Comment (if applicable, please state your preferred regimen):

14. Under exceptional circumstances like the COVID-19 outbreak in which routine surgical management is unlikely; For a new postmenopausal patient with stage T1NOMO, grade 2, luminal B-like (HER2-negative/HR-low positive/Ki67 > 15\%) tumor, giving neoadjuvant chemotherapy alone (4-6 months) with any relevant regimen is suitable.

$\begin{array}{ccccccccc}1 & 2 & 3 & 4 & 5 & 6 & 7 & 8 & 9 \\ \text { Strongly Disagree } & & & & & & & & \text { Strongly agree }\end{array}$

Comment: Comment (if applicable, please state your preferred regimen): 
SUPPLEMENT. National Consensus on Breast Cancer Management During Temporary State of Emergency Due to COVID-19 Outbreak in Turkey (continue)

\section{In patients with triple negative tumor who had complete clinical response following neoadjuvant chemotherapy:}

15. Under exceptional circumstances like the COVID-19 outbreak in which routine surgical management is unlikely; For a premenopausal patient with triple negative tumor who had "complete" clinical response after NST, giving extended systemic treatment with any relevant regimen (with or without RT) is suitable.

$\begin{array}{ccccccccc}1 & 2 & 3 & 4 & 5 & 6 & 7 & 8 & 9 \\ \text { Strongly Disagree } & & & & & & & & \text { Strongly agree }\end{array}$

Comment: Comment (if applicable, please state your preferred regimen):

16. Under exceptional circumstances like the COVID-19 outbreak in which routine surgical management is unlikely; For a premenopausal patient with triple negative tumor who had "complete" clinical response after NST, giving loco-regional RT without any further systemic treatment is suitable.

$\begin{array}{ccccccccc}1 & 2 & 3 & 4 & 5 & 6 & 7 & 8 & 9 \\ \text { Strongly Disagree } & & & & & & & & \end{array}$

Comment:

17. Under exceptional circumstances like the COVID-19 outbreak in which routine surgical management is unlikely; For a postmenopausal patient with triple negative tumor who had "complete" clinical response after NST, giving extended systemic treatment with any relevant regimen (with or without RT) is suitable.

$\begin{array}{ccccccccc}1 & 2 & 3 & 4 & 5 & 6 & 7 & 8 & 9 \\ \text { Strongly Disagree } & & & & & & & & \text { Strongly agree }\end{array}$

Comment: Comment (if applicable, please state your preferred regimen):

18. Under exceptional circumstances like the COVID-19 outbreak in which routine surgical management is unlikely; For a postmenopausal patient with triple negative tumor who had "complete" clinical response after NST, giving loco-regional RT without any further systemic treatment is suitable.

$\begin{array}{ccccccccc}1 & 2 & 3 & 4 & 5 & 6 & 7 & 8 & 9 \\ \text { Strongly Disagree } & & & & & & & & \text { Strongly agree }\end{array}$

Comment:

In patients with triple negative tumor who had partial clinical response following neoadjuvant chemotherapy:

19. Under exceptional circumstances like the COVID-19 outbreak in which routine surgical management is unlikely; For a premenopausal patient with triple negative tumor who had "partial" clinical response after NST, giving extended systemic treatment with any relevant regimen (with or without RT) is suitable.

$\begin{array}{ccccccccc}1 & 2 & 3 & 4 & 5 & 6 & 7 & 8 & 9 \\ \text { Strongly Disagree } & & & & & & & & \text { Strongly agree }\end{array}$

Comment: Comment (if applicable, please state your preferred regimen):

20. Under exceptional circumstances like the COVID-19 outbreak in which routine surgical management is unlikely; For a premenopausal patient with triple negative tumor who had "partial" clinical response after NST, giving loco-regional RT without any further systemic treatment is suitable.

$\begin{array}{ccccccccc}1 & 2 & 3 & 4 & 5 & 6 & 7 & 8 & 9 \\ \text { Strongly Disagree } & & & & & & & & \end{array}$

Comment:

21. Under exceptional circumstances like the COVID-19 outbreak in which routine surgical management is unlikely; For a postmenopausal patient with triple negative tumor who had "partial" clinical response after NST, giving extended systemic treatment with any relevant regimen (with or without RT) is suitable.

$\begin{array}{ccccccccc}1 & 2 & 3 & 4 & 5 & 6 & 7 & 8 & 9 \\ \text { Strongly Disagree } & & & & & & & & \end{array}$

Comment: Comment (if applicable, please state your preferred regimen): 
SUPPLEMENT. National Consensus on Breast Cancer Management During Temporary State of Emergency Due to COVID-19 Outbreak in Turkey (continue)

22. Under exceptional circumstances like the COVID-19 outbreak in which routine surgical management is unlikely; For a postmenopausal patient with triple negative tumor who had "partial" clinical response after NST, giving loco-regional RT without any further systemic treatment is suitable. $\begin{array}{ccccccccc}1 & 2 & 3 & 4 & 5 & 6 & 7 & 8 & 9 \\ \text { Strongly Disagree } & & & & & & & & \end{array}$

Comment:

In patients with HER2-positive/HR-negative tumor who had complete clinical response following neoadjuvant chemotherapy:

23. Under exceptional circumstances like the COVID-19 outbreak in which routine surgical management is unlikely; For a premenopausal patient with HER2-positive/HR-negative tumor who had "complete" clinical response after NST, continuing with anti-HER2 treatment alone with any relevant regimen (with or without $\mathrm{RT}$ ) is suitable.

$\begin{array}{ccccccccc}1 & 2 & 3 & 4 & 5 & 6 & 7 & 8 & 9 \\ \text { Strongly Disagree } & & & & & & & & \text { Strongly agree }\end{array}$

Comment: Comment (if applicable, please state your preferred regimen):

24. Under exceptional circumstances like the COVID-19 outbreak in which routine surgical management is unlikely; For a premenopausal patient with HER2-positive/HR-negative tumor who had "complete" clinical response after NST, continuing with anti-HER2 treatment and extended chemotherapy with any relevant regimen (with or without RT) is suitable.

$\begin{array}{ccccccccc}1 & 2 & 3 & 4 & 5 & 6 & 7 & 8 & 9 \\ \text { Strongly Disagree } & & & & & & & & \text { Strongly agree }\end{array}$

Comment: Comment (if applicable, please state your preferred regimen):

25. Under exceptional circumstances like the COVID-19 outbreak in which routine surgical management is unlikely; For a postmenopausal patient with HER2-positive/HR-negative tumor who had "complete" clinical response after NST, continuing with anti-HER2 treatment alone with any relevant regimen (with or without $\mathrm{RT}$ ) is suitable.

$\begin{array}{ccccccccc}1 & 2 & 3 & 4 & 5 & 6 & 7 & 8 & 9 \\ \text { Strongly Disagree } & & & & & & & & \text { Strongly agree }\end{array}$

Comment: Comment (if applicable, please state your preferred regimen):

26. Under exceptional circumstances like the COVID-19 outbreak in which routine surgical management is unlikely; For a postmenopausal patient with HER2-positive/HR-negative tumor who had "complete" clinical response after NST, continuing with anti-HER2 treatment and extended chemotherapy with any relevant regimen (with or without RT) is suitable.

$\begin{array}{ccccccccc}1 & 2 & 3 & 4 & 5 & 6 & 7 & 8 & 9 \\ \text { Strongly Disagree } & & & & & & & & \text { Strongly agree }\end{array}$

Comment: Comment (if applicable, please state your preferred regimen):

In patients with HER2-positive/HR-negative tumor who had partial clinical response following neoadjuvant chemotherapy:

27. Under exceptional circumstances like the COVID-19 outbreak in which routine surgical management is unlikely; For a premenopausal patient with HER2-positive/HR-negative tumor who had "partial" clinical response after NST, continuing with anti-HER2 treatment alone with any relevant regimen (with or without $\mathrm{RT}$ ) is suitable.

$\begin{array}{ccccccccc}1 & 2 & 3 & 4 & 5 & 6 & 7 & 8 & 9 \\ \text { Strongly Disagree } & & & & & & & & \text { Strongly agree }\end{array}$

Comment: Comment (if applicable, please state your preferred regimen):

28. Under exceptional circumstances like the COVID-19 outbreak in which routine surgical management is unlikely; For a premenopausal patient with HER2-positive/HR-negative tumor who had "partial" clinical response after NST, continuing with anti-HER2 treatment and extended chemotherapy with any relevant regimen (with or without RT) is suitable.

$\begin{array}{ccccccccc}1 & 2 & 3 & 4 & 5 & 6 & 7 & 8 & 9 \\ \text { Strongly Disagree } & & & & & & & & \text { Strongly agree }\end{array}$

Comment: Comment (if applicable, please state your preferred regimen): 
SUPPLEMENT. National Consensus on Breast Cancer Management During Temporary State of Emergency Due to COVID-19 Outbreak in Turkey (continue)

29. Under exceptional circumstances like the COVID-19 outbreak in which routine surgical management is unlikely; For a postmenopausal patient with HER2-positive/HR-negative tumor who had "partial" clinical response after NST, continuing with anti-HER2 treatment alone with any relevant regimen (with or without $\mathrm{RT}$ ) is suitable.

$\begin{array}{ccccccccc}1 & 2 & 3 & 4 & 5 & 6 & 7 & 8 & 9 \\ \text { Strongly Disagree } & & & & & & & & \text { Strongly agree }\end{array}$

Comment: Comment (if applicable, please state your preferred regimen):

30. Under exceptional circumstances like the COVID-19 outbreak in which routine surgical management is unlikely; For a postmenopausal patient with HER2-positive/HR-negative tumor who had "partial" clinical response after NST, continuing with anti-HER2 treatment and extended chemotherapy with any relevant regimen (with or without RT) is suitable.

$\begin{array}{ccccccccc}1 & 2 & 3 & 4 & 5 & 6 & 7 & 8 & 9 \\ \text { Strongly Disagree } & & & & & & & & \text { Strongly agree }\end{array}$

Comment: (if applicable, please state your preferred regimen):

\section{In patients with HER2-positive/HR-positive tumor who had complete clinical response following neoadjuvant chemotherapy:}

31. Under exceptional circumstances like the COVID-19 outbreak in which routine surgical management is unlikely; For a premenopausal patient with HER2-positive/HR-positive tumor who had "complete" clinical response after NST, continuing with anti-HER2 and endocrine treatments with any relevant regimen (with or without RT) is suitable.

$\begin{array}{ccccccccc}1 & 2 & 3 & 4 & 5 & 6 & 7 & 8 & 9 \\ \text { Strongly Disagree } & & & & & & & & \text { Strongly agree }\end{array}$

Comment: (if applicable, please state your preferred regimen):

32. Under exceptional circumstances like the COVID-19 outbreak in which routine surgical management is unlikely; For a premenopausal patient with HER2-positive/HR-positive tumor who had "complete" clinical response after NST, continuing with anti-HER2 treatment alone with any relevant regimen (with or without $\mathrm{RT}$ ) is suitable.

$\begin{array}{ccccccccc}1 & 2 & 3 & 4 & 5 & 6 & 7 & 8 & 9 \\ \text { Strongly Disagree } & & & & & & & & \text { Strongly agree }\end{array}$

Comment: (if applicable, please state your preferred regimen):

33. Under exceptional circumstances like the COVID-19 outbreak in which routine surgical management is unlikely; For a postmenopausal patient with HER2-positive/HR-positive tumor who had "complete" clinical response after NST, continuing with anti-HER2 and endocrine treatments with any relevant regimen (with or without RT) is suitable.

$\begin{array}{ccccccccc}1 & 2 & 3 & 4 & 5 & 6 & 7 & 8 & 9 \\ \text { Strongly Disagree } & & & & & & & & \text { Strongly agree }\end{array}$

Comment: (if applicable, please state your preferred regimen):

34. Under exceptional circumstances like the COVID-19 outbreak in which routine surgical management is unlikely; For a postmenopausal patient with HER2-positive/HR-positive tumor who had "complete" clinical response after NST, continuing with anti-HER2 treatment alone with any relevant regimen (with or without RT) is suitable.

$\begin{array}{ccccccccc}1 & 2 & 3 & 4 & 5 & 6 & 7 & 8 & 9 \\ \text { Strongly Disagree } & & & & & & & & \text { Strongly agree }\end{array}$

Comment: (if applicable, please state your preferred regimen):

\section{In patients with HER2-positive/HR-positive tumor who had partial clinical response following neoadjuvant chemotherapy:}

35. Under exceptional circumstances like the COVID-19 outbreak in which routine surgical management is unlikely; For a premenopausal patient with HER2-positive/HR-positive tumor who had "partial" clinical response after NST, continuing with anti-HER2 and endocrine treatments with any relevant regimen (with or without RT) is suitable.

$\begin{array}{ccccccccc}1 & 2 & 3 & 4 & 5 & 6 & 7 & 8 & 9 \\ \text { Strongly Disagree } & & & & & & & & \text { Strongly agree }\end{array}$

Comment: (if applicable, please state your preferred regimen): 
SUPPLEMENT. National Consensus on Breast Cancer Management During Temporary State of Emergency Due to COVID-19 Outbreak in Turkey (continue)

36. Under exceptional circumstances like the COVID-19 outbreak in which routine surgical management is unlikely; For a premenopausal patient with HER2-positive/HR-positive tumor who had "partial" clinical response after NST, continuing with anti-HER2 treatment alone with any relevant regimen (with or without $\mathrm{RT}$ ) is suitable.

$\begin{array}{ccccccccc}1 & 2 & 3 & 4 & 5 & 6 & 7 & 8 & 9 \\ \text { Strongly Disagree } & & & & & & & & \text { Strongly agree }\end{array}$

Comment: (if applicable, please state your preferred regimen):

37. Under exceptional circumstances like the COVID-19 outbreak in which routine surgical management is unlikely; For a postmenopausal patient with HER2-positive/HR-positive tumor who had "partial" clinical response after NST, continuing with anti-HER2 and endocrine treatments with any relevant regimen (with or without $\mathrm{RT}$ ) is suitable.

$\begin{array}{ccccccccc}1 & 2 & 3 & 4 & 5 & 6 & 7 & 8 & 9 \\ \text { Strongly Disagree } & & & & & & & & \text { Strongly agree }\end{array}$

Comment: (if applicable, please state your preferred regimen):

38. Under exceptional circumstances like the COVID-19 outbreak in which routine surgical management is unlikely; For a postmenopausal patient with HER2-positive/HR-positive tumor who had "partial" clinical response after NST, continuing with anti-HER2 treatment alone with any relevant regimen (with or without $\mathrm{RT}$ ) is suitable

$\begin{array}{ccccccccc}1 & 2 & 3 & 4 & 5 & 6 & 7 & 8 & 9 \\ \text { Strongly Disagree } & & & & & & & & \text { Strongly agree }\end{array}$

Comment: (if applicable, please state your preferred regimen):

In patients with luminal B-like (HER2-negative) tumor with complete clinical response following neoadjuvant chemotherapy:

39. Under exceptional circumstances like the COVID-19 outbreak in which routine surgical management is unlikely; For a premenopausal patient with luminal B-like (HER2-negative) tumor who had "complete" clinical response after NST, giving endocrine treatment only with any relevant regimen (with or without RT) is suitable.

$\begin{array}{ccccccccc}1 & 2 & 3 & 4 & 5 & 6 & 7 & 8 & 9 \\ \text { Strongly Disagree } & & & & & & & & \text { Strongly agree }\end{array}$

Comment: (if applicable, please state your preferred regimen):

40. Under exceptional circumstances like the COVID-19 outbreak in which routine surgical management is unlikely; For a premenopausal patient with luminal B-like (HER2-negative) tumor who had "complete" clinical response after NST, giving extended chemotherapy with any relevant regimen (with or without RT) is suitable.

$\begin{array}{ccccccccc}1 & 2 & 3 & 4 & 5 & 6 & 7 & 8 & 9 \\ \text { Strongly Disagree } & & & & & & & & \text { Strongly agree }\end{array}$

Comment: (if applicable, please state your preferred regimen):

41. Under exceptional circumstances like the COVID-19 outbreak in which routine surgical management is unlikely; For a postmenopausal patient with luminal B-like (HER2-negative) tumor who had "complete" clinical response after NST, giving endocrine treatment only with any relevant regimen (with or without $\mathrm{RT}$ ) is suitable.

$\begin{array}{ccccccccc}1 & 2 & 3 & 4 & 5 & 6 & 7 & 8 & \begin{array}{c}9 \\ \text { Strongly agree }\end{array} \\ \text { Strongly Disagree } & & & & & & & & \end{array}$

Comment: (if applicable, please state your preferred regimen):

42. Under exceptional circumstances like the COVID-19 outbreak in which routine surgical management is unlikely; For a postmenopausal patient with luminal B-like (HER2-negative) tumor who had "complete" clinical response after NST, giving extended chemotherapy only with any relevant regimen (with or without $\mathrm{RT}$ ) is suitable.

$\begin{array}{ccccccccc}1 & 2 & 3 & 4 & 5 & 6 & 7 & 8 & 9 \\ \text { Strongly Disagree } & & & & & & & & \text { Strongly agree }\end{array}$

Comment: (if applicable, please state your preferred regimen): 
SUPPLEMENT. National Consensus on Breast Cancer Management During Temporary State of Emergency Due to COVID-19 Outbreak in Turkey (continue)

In patients with luminal B-like (HER2-negative) tumor with partial clinical response following neoadjuvant chemotherapy:

43. Under exceptional circumstances like the COVID-19 outbreak in which routine surgical management is unlikely; For a premenopausal I patient with luminal B-like (HER2-negative) tumor who had "partial" clinical response after NST, giving endocrine treatment only with any relevant regimen (with or without RT) is suitable.

$\begin{array}{ccccccccc}1 & 2 & 3 & 4 & 5 & 6 & 7 & 8 & 9 \\ \text { Strongly Disagree } & & & & & & & & \text { Strongly agree }\end{array}$

Comment: (if applicable, please state your preferred regimen):

44. Under exceptional circumstances like the COVID-19 outbreak in which routine surgical management is unlikely; For a premenopausal patient with luminal B-like (HER2-negative) tumor who had "partial" clinical response after NST, giving extended chemotherapy only with any relevant regimen (with or without RT) is suitable.

$\begin{array}{ccccccccc}1 & 2 & 3 & 4 & 5 & 6 & 7 & 8 & 9 \\ \text { Strongly Disagree } & & & & & & & & \text { Strongly agree }\end{array}$

Comment: (if applicable, please state your preferred regimen):

45. Under exceptional circumstances like the COVID-19 outbreak in which routine surgical management is unlikely; For a postmenopausal patient with luminal B-like (HER2-negative) tumor who had "partial" clinical response after NST, giving endocrine treatment only with relevant regimen (with or without RT) is suitable.

$\begin{array}{ccccccccc}1 & 2 & 3 & 4 & 5 & 6 & 7 & 8 & 9 \\ \text { Strongly Disagree } & & & & & & & & \text { Strongly agree }\end{array}$

Comment: (if applicable, please state your preferred regimen):

46. Under exceptional circumstances like the COVID-19 outbreak in which routine surgical management is unlikely; For a postmenopausal patient with luminal B-like (HER2-negative) tumor who had "partial" clinical response after NST, giving extended chemotherapy with relevant regimen (with or without RT) is suitable.

$\begin{array}{ccccccccc}1 & 2 & 3 & 4 & 5 & 6 & 7 & 8 & 9 \\ \text { Strongly Disagree } & & & & & & & & \text { Strongly agree }\end{array}$

Comment: (if applicable, please state your preferred regimen):

scenarios (one for each). Overall, thirty-two statements were rejected, and the remaining nine received votes which did not exceed any required threshold for a decision.

After considering comments obtained from the first round, the remaining inconclusive statements (Statement no: 2, 5, 6, 7, 25, $31,33,39$ and 41 ) for 9 case scenarios were sent to the panelists for re-voting at a second round. The new round started on April $5^{\text {th }}, 2020$ and finished on April $7^{\text {th }}, 2020$. At this round, 45 panelists voted, and therefore the quorum (59\%) was attained. Of those who voted at this round, 35 were breast surgeons and 10 were medical oncologists. All statements at the second round were endorsed as recommendation by the panel. Therefore, overall 14 statements were endorsed as recommendation for 14 case scenarios (one for each). Whereas, the panel did not endorse any statement for the remaining 14 case scenarios as recommendation after two rounds of consensus.

Briefly, the panel endorsed statements for replacing surgery with minimum one alternative treatment in patients with node-negative triple negative, HER2-positive and luminal A-like tumors. The panel endorsed giving NST with relevant regimen accordingly for 4-6 months to all patients with node-negative, stage I, triple negative and HER2-positive [both hormone receptor (HR) positive and negative] tumors until the surgical procedure was deemed to be feasible in situations where there was no clear indication for NST. The panel also endorsed giving neoadjuvant ET for 4-6 months until due surgery to all patients with low-risk luminal A-like (node-negative, early stage, high HR-positivity, low grade, low Ki67) tumor as well as to postmenopausal patients with limited node-positive luminal A-like tumor.

For patients with HER2-positive/HR-negative tumor who had clinical complete response (cCR) after NST, the panelists overwhelmingly agreed on giving antiHER2 treatment (with or without RT) for a temporary period in postmenopausal patients if surgery was not feasible. Furthermore, provided with the same circumstances, for those patients with HER2-positive/HR-positive tumors who had CCR after NST, the panelists endorsed giving both antiHER2 and ET (with or without RT) in all patients.

Finally, for patients with luminal B-like (HER2-negative/HR-low positive) tumor who had CCR after NST, panelists endorsed the alternative treatment with ET only (with or without RT) in all patients if surgery could not be performed (Table 1). 
Table 1. Statements and voting results accordingly

Condition: In patients who are physically fit and without any co-morbidity and under exceptional circumstances like the COVID-19 outbreak in which routine surgical management of breast cancer is suspended for a temporary period of time.

\begin{tabular}{|c|c|c|c|c|}
\hline \multirow{2}{*}{$\begin{array}{l}\text { Recommendation } \\
\text { In newly admitted patients with invasive breast cancer diagnosis: }\end{array}$} & \multicolumn{3}{|c|}{ Voting counts } & \multirow[t]{2}{*}{ Result } \\
\hline & Disagree & Abstain & Agree & \\
\hline $\begin{array}{l}\text { 1. For a new premenopausal patient with stage } T 1 \mathrm{NOM0} \text {, grade } 3 \text {, triple negative } \\
\text { (HER2-negative/HR-negative) tumor, giving NST ( } 4-6 \text { months) with any relevant re- } \\
\text { gimen* is suitable. }\end{array}$ & $14 \%$ & $10 \%$ & $76 \%$ & Endorsed \\
\hline $\begin{array}{l}\text { 2. For a new postmenopausal patient with stage T1NOMO, grade 3, triple negative } \\
\text { (HER2-negative/HR-negative) tumor, giving NST ( } 4-6 \text { months) with any relevant re- } \\
\text { gimen is suitable. }\end{array}$ & $4 \%$ & $3 \%$ & $93 \%$ & Endorsed \\
\hline $\begin{array}{l}\text { 3. For a new premenopausal patient with stage T1NOM0, grade } 3 \text {, } \\
\text { HER2-positive/HR-negative tumor, giving NST ( } 4-6 \text { months) with any relevant regi- } \\
\text { men is suitable. }\end{array}$ & $10 \%$ & $14 \%$ & $76 \%$ & Endorsed \\
\hline $\begin{array}{l}\text { 4. For a new postmenopausal patient with stage T1NOMO, grade } 3 \text {, } \\
\text { HER2-positive/HR-negative tumor, giving NST ( } 4-6 \text { months) with any relevant regi- } \\
\text { men is suitable. }\end{array}$ & $10 \%$ & $15 \%$ & $75 \%$ & Endorsed \\
\hline $\begin{array}{l}\text { 5. For a new premenopausal patient with stage T1NOMO, grade } 3 \text {, } \\
\text { HER2-positive/HR-positive tumor, giving NST ( } 4-6 \text { months) with any relevant regi- } \\
\text { men is suitable. }\end{array}$ & $2 \%$ & $9 \%$ & $89 \%$ & Endorsed \\
\hline $\begin{array}{l}\text { 6. For a new postmenopausal patient with stage T1NOM0, grade } 3 \text {, } \\
\text { HER2-positive/HR-positive tumor, giving NST ( } 4-6 \text { months) with any relevant regi- } \\
\text { men is suitable. }\end{array}$ & $1 \%$ & $0 \%$ & $99 \%$ & Endorsed \\
\hline $\begin{array}{l}\text { 7. For a new premenopausal patient with stage T1NOMO, grade 1, luminal A-like } \\
\text { (HER2-negative/HR-highly positive/Ki67 < 15\%) tumor, giving neoadjuvant endocri- } \\
\text { ne treatment alone ( } 4-6 \text { months) with any relevant regimen is suitable. }\end{array}$ & $4 \%$ & $9 \%$ & $87 \%$ & Endorsed \\
\hline $\begin{array}{l}\text { 8. For a new postmenopausal patient with stage T1N0M0, grade 1, luminal A-like } \\
\text { (HER2-negative/HR-highly positive/Ki67 < 15\%) tumor, giving neoadjuvant endocri- } \\
\text { ne treatment alone ( } 4-6 \text { months) with any relevant regimen is suitable. }\end{array}$ & $10 \%$ & $4 \%$ & $86 \%$ & Endorsed \\
\hline $\begin{array}{l}\text { 9. For a new premenopausal patient with stage } \mathrm{T1}-2 \mathrm{~N} 1 \mathrm{M} 0 \text {, grade } 2 \text {, luminal A-like } \\
\text { (HER2-negative/HR-highly positive/Ki67 < 15\%) tumor, giving neoadjuvant endocri- } \\
\text { ne treatment alone ( } 4-6 \text { months) with any relevant regimen is suitable. }\end{array}$ & $27 \%$ & $18 \%$ & $55 \%$ & Rejected \\
\hline $\begin{array}{l}\text { 10. For a new postmenopausal patient with stage T1-2N1M0, grade } 2 \text {, luminal A-like } \\
\text { (HER2-negative/HR-highly positive/Ki67 < 15\%) tumor, giving neoadjuvant endocri- } \\
\text { ne treatment alone ( } 4-6 \text { months) with any relevant regimen is suitable. }\end{array}$ & $10 \%$ & $12 \%$ & $78 \%$ & Endorsed \\
\hline $\begin{array}{l}\text { 11. For a new premenopausal patient with stage T1NOM0, grade 2, luminal B-like } \\
\text { (HER2-negative/HR-low positive/Ki67 > 15\%) tumor, giving neoadjuvant endocrine } \\
\text { treatment alone ( } 4-6 \text { months) with any relevant regimen is suitable. }\end{array}$ & $50 \%$ & $23 \%$ & $27 \%$ & Rejected \\
\hline $\begin{array}{l}\text { 12. For a new premenopausal patient with stage T1NOM0, grade } 2 \text {, luminal B-like } \\
\text { (HER2-negative/HR-low positive/Ki67 > 15\%) tumor, giving neoadjuvant chemothe- } \\
\text { rapy alone ( } 4-6 \text { months) with any relevant regimen is suitable. }\end{array}$ & $25 \%$ & $26 \%$ & $49 \%$ & Rejected \\
\hline $\begin{array}{l}\text { 13. For a new postmenopausal patient with stage T1N0M0, grade 2, luminal B-like } \\
\text { (HER2-negative/HR-low positive/Ki67 > 15\%) tumor, giving neoadjuvant endocrine } \\
\text { treatment alone ( } 4-6 \text { months) with any relevant regimen is suitable. }\end{array}$ & $29 \%$ & $32 \%$ & $39 \%$ & Rejected \\
\hline $\begin{array}{l}\text { 14. For a new postmenopausal patient with stage T1N0M0, grade 2, luminal B-like } \\
\text { (HER2-negative/HR-low positive/Ki67 > 15\%) tumor, giving neoadjuvant chemothe- } \\
\text { rapy alone ( } 4-6 \text { months) with any relevant regimen is suitable. }\end{array}$ & $25 \%$ & $18 \%$ & $57 \%$ & Rejected \\
\hline
\end{tabular}


Table 1. Statements and voting results accordingly (continue)

Condition: In patients who are physically fit and without any co-morbidity and under exceptional circumstances like the COVID-19 outbreak in which routine surgical management of breast cancer is suspended for a temporary period of time.

\begin{tabular}{|c|c|c|c|c|}
\hline \multirow{2}{*}{$\begin{array}{l}\text { Recommendation } \\
\text { After completion of NST in triple negative tumor: }\end{array}$} & \multicolumn{3}{|c|}{ Voting counts } & \multirow[t]{2}{*}{ Result } \\
\hline & Disagree & Abstain & Agree & \\
\hline $\begin{array}{l}\text { 15. For a premenopausal patient with triple negative tumor who had cCR after NST, } \\
\text { giving extended systemic treatment with any relevant regimen (with or without RT) } \\
\text { is suitable. }\end{array}$ & $53 \%$ & $16 \%$ & $31 \%$ & Rejected \\
\hline $\begin{array}{l}\text { 16. For a premenopausal patient with triple negative tumor who had cCR after NST, } \\
\text { giving loco-regional RT without any further systemic treatment is suitable. }\end{array}$ & $57 \%$ & $19 \%$ & $24 \%$ & Rejected \\
\hline $\begin{array}{l}\text { 17. For a postmenopausal patient with triple negative tumor who had cCR after NST, } \\
\text { giving extended systemic treatment with any relevant regimen (with or without RT) } \\
\text { is suitable. }\end{array}$ & $49 \%$ & $24 \%$ & $27 \%$ & Rejected \\
\hline $\begin{array}{l}\text { 18. For a postmenopausal patient with triple negative tumor who had cCR after NST, } \\
\text { giving loco-regional RT without any further systemic treatment is suitable. }\end{array}$ & $47 \%$ & $20 \%$ & $33 \%$ & Rejected \\
\hline $\begin{array}{l}\text { 19. For a premenopausal patient with triple negative tumor who had cPR after NST, } \\
\text { giving extended systemic treatment with any relevant regimen (with or without RT) } \\
\text { is suitable. }\end{array}$ & $49 \%$ & $27 \%$ & $24 \%$ & Rejected \\
\hline $\begin{array}{l}\text { 20. For a premenopausal patient with triple negative tumor who had CPR after NST, } \\
\text { giving loco-regional RT without any further systemic treatment is suitable. }\end{array}$ & $82 \%$ & $10 \%$ & $8 \%$ & Rejected \\
\hline $\begin{array}{l}\text { 21. For a postmenopausal patient with triple negative tumor who had cPR after NST, } \\
\text { giving extended systemic treatment with any relevant regimen (with or without RT) } \\
\text { is suitable. }\end{array}$ & $53 \%$ & $20 \%$ & $27 \%$ & Rejected \\
\hline $\begin{array}{l}\text { 22. For a postmenopausal patient with triple negative tumor who had cPR after NST, } \\
\text { giving loco-regional RT without any further systemic treatment is suitable. }\end{array}$ & $67 \%$ & $21 \%$ & $12 \%$ & Rejected \\
\hline After completion of NST in HER2-positive/HR-negative tumor: & Disagree & Abstain & Agree & \\
\hline $\begin{array}{l}\text { 23. For a premenopausal patient with HER2-positive/HR-negative tumor who had } \\
\text { CCR after NST, continuing with anti-HER2 treatment alone with any relevant regimen } \\
\text { (with or without RT) is suitable. }\end{array}$ & $25 \%$ & $20 \%$ & $55 \%$ & Rejected \\
\hline $\begin{array}{l}\text { 24. For a premenopausal patient with HER2-positive/HR-negative tumor who had } \\
\text { CCR after NST, continuing with anti-HER2 treatment and extended chemotherapy } \\
\text { with any relevant regimen (with or without RT) is suitable. }\end{array}$ & $33 \%$ & $20 \%$ & $47 \%$ & Rejected \\
\hline $\begin{array}{l}\text { 25. For a postmenopausal patient with HER2-positive/HR-negative tumor who had } \\
\text { CCR after NST, continuing with anti-HER2 treatment alone with any relevant regimen } \\
\text { (with or without RT) is suitable. }\end{array}$ & $11 \%$ & $2 \%$ & $87 \%$ & Endorsed \\
\hline $\begin{array}{l}\text { 26. For a postmenopausal patient with HER2-positive/HR-negative tumor who had } \\
\text { cCR after NST, continuing with anti-HER2 treatment and extended chemotherapy } \\
\text { with any relevant regimen (with or without RT) is suitable. }\end{array}$ & $33 \%$ & $26 \%$ & $41 \%$ & Rejected \\
\hline $\begin{array}{l}\text { 27. For a premenopausal patient with HER2-positive/HR-negative tumor who had } \\
\text { CPR clinical response after NST, continuing with anti-HER2 treatment alone with any } \\
\text { relevant regimen (with or without RT) is suitable. }\end{array}$ & $53 \%$ & $22 \%$ & $25 \%$ & Rejected \\
\hline $\begin{array}{l}\text { 28. For a premenopausal patient with HER2-positive/HR-negative tumor who had } \\
\text { CPR after NST, continuing with anti-HER2 treatment and extended chemotherapy } \\
\text { with any relevant regimen (with or without RT) is suitable. }\end{array}$ & $43 \%$ & $30 \%$ & $27 \%$ & Rejected \\
\hline $\begin{array}{l}\text { 29. For a postmenopausal patient with HER2-positive/HR-negative tumor who had } \\
\text { CPR after NST, continuing with anti-HER2 treatment alone with any relevant regimen } \\
\text { (with or without RT) is suitable. }\end{array}$ & $39 \%$ & $24 \%$ & $37 \%$ & Rejected \\
\hline
\end{tabular}


Table 1. Statements and voting results accordingly (continue)

Condition: In patients who are physically fit and without any co-morbidity and under exceptional circumstances like the COVID-19 outbreak in which routine surgical management of breast cancer is suspended for a temporary period of time.

\begin{tabular}{|c|c|c|c|c|}
\hline \multirow[t]{2}{*}{ Recommendation } & \multicolumn{3}{|c|}{ Voting counts } & \multirow[t]{2}{*}{ Result } \\
\hline & Disagree & Abstain & Agree & \\
\hline $\begin{array}{l}\text { 30. For a postmenopausal patient with HER2-positive/HR-negative tumor who had } \\
\text { CPR after NST, continuing with anti-HER2 treatment and extended chemotherapy } \\
\text { with any relevant regimen (with or without RT) is suitable. }\end{array}$ & $31 \%$ & $40 \%$ & $29 \%$ & Rejected \\
\hline After completion of NST in HER2-positive/HR-positive tumor: & Disagree & Abstain & Agree & \\
\hline $\begin{array}{l}\text { 31. For a premenopausal patient with HER2-positive/HR-positive tumor who had } \\
\text { CCR after NST, continuing with anti-HER2 and endocrine treatments with any rele- } \\
\text { vant regimen (with or without RT) is suitable. }\end{array}$ & $9 \%$ & $7 \%$ & $84 \%$ & Endorsed \\
\hline $\begin{array}{l}\text { 32. For a premenopausal patient with HER2-positive/HR-positive tumor who had } \\
\text { CCR after NST, continuing with anti-HER2 treatment alone with any relevant regimen } \\
\text { (with or without RT) is suitable. }\end{array}$ & $45 \%$ & $30 \%$ & $25 \%$ & Rejected \\
\hline $\begin{array}{l}\text { 33. For a postmenopausal patient with HER2-positive/HR-positive tumor who had } \\
\text { CCR after NST, continuing with anti-HER2 and endocrine treatments with any rele- } \\
\text { vant regimen (with or without RT) is suitable. }\end{array}$ & $9 \%$ & $2 \%$ & $89 \%$ & Endorsed \\
\hline $\begin{array}{l}\text { 34. For a postmenopausal patient with HER2-positive/HR-positive tumor who had } \\
\text { CCR after NST, continuing with anti-HER2 treatment alone with any relevant regimen } \\
\text { (with or without RT) is suitable. }\end{array}$ & $55 \%$ & $16 \%$ & $29 \%$ & Rejected \\
\hline $\begin{array}{l}\text { 35. For a premenopausal patient with HER2-positive/HR-positive tumor who had } \\
\text { CPR after NST, continuing with anti-HER2 and endocrine treatments with any rele- } \\
\text { vant regimen (with or without RT) is suitable. }\end{array}$ & $49 \%$ & $12 \%$ & $39 \%$ & Rejected \\
\hline $\begin{array}{l}\text { 36. For a premenopausal patient with HER2-positive/HR-positive tumor who had } \\
\text { CPR after NST, continuing with anti-HER2 treatment alone with any relevant regimen } \\
\text { (with or without RT) is suitable. }\end{array}$ & $63 \%$ & $6 \%$ & $31 \%$ & Rejected \\
\hline $\begin{array}{l}\text { 37. For a postmenopausal patient with HER2-positive/HR-positive tumor who had } \\
\text { CPR after NST, continuing with anti-HER2 and endocrine treatments with any rele- } \\
\text { vant regimen (with or without RT) is suitable. }\end{array}$ & $41 \%$ & $10 \%$ & $49 \%$ & Rejected \\
\hline $\begin{array}{l}\text { 38. For a postmenopausal patient with HER2-positive/HR-positive tumor who had } \\
\text { CPR after NST, continuing with anti-HER2 treatment alone with any relevant regimen } \\
\text { (with or without RT) is suitable. }\end{array}$ & $61 \%$ & $15 \%$ & $24 \%$ & Rejected \\
\hline After completion of NST in luminal B-like (HER2-negative) tumor: & Disagree & Abstain & Agree & \\
\hline $\begin{array}{l}\text { 39. For a premenopausal patient with luminal B-like (HER2-negative) tumor } \\
\text { who had CCR after NST, giving endocrine treatment only with any relevant regimen } \\
\text { (with or without RT) is suitable. }\end{array}$ & $11 \%$ & $11 \%$ & $78 \%$ & Endorsed \\
\hline $\begin{array}{l}\text { 40. For a premenopausal patient with luminal B-like (HER2-negative) tumor } \\
\text { who had cCR after NST, giving extended chemotherapy with any relevant regimen } \\
\text { (with or without RT) is suitable. }\end{array}$ & $53 \%$ & $23 \%$ & $24 \%$ & Rejected \\
\hline $\begin{array}{l}\text { 41. For a postmenopausal patient with luminal B-like (HER2-negative) tumor who } \\
\text { had CCR after NST, giving endocrine treatment only with any relevant regimen (with } \\
\text { or without RT) is suitable. }\end{array}$ & $9 \%$ & $4 \%$ & $87 \%$ & Endorsed \\
\hline $\begin{array}{l}\text { 42. For a postmenopausal patient with luminal B-like (HER2-negative) tumor who } \\
\text { had CCR after NST, giving extended chemotherapy only with any relevant regimen } \\
\text { (with or without RT) is suitable. }\end{array}$ & $59 \%$ & $17 \%$ & $24 \%$ & Rejected \\
\hline
\end{tabular}


Table 1. Statements and voting results accordingly (continue)

Condition: In patients who are physically fit and without any co-morbidity and under exceptional circumstances like the COVID-19 outbreak in which routine surgical management of breast cancer is suspended for a temporary period of time.

\begin{tabular}{|c|c|c|c|c|}
\hline \multirow[t]{2}{*}{ Recommendation } & \multicolumn{3}{|c|}{ Voting counts } & \multirow[t]{2}{*}{ Result } \\
\hline & Disagree & Abstain & Agree & \\
\hline $\begin{array}{l}\text { 43. For a premenopausal patient with luminal B-like (HER2-negative) tumor who had } \\
\text { CPR after NST, giving endocrine treatment only with any relevant regimen (with or } \\
\text { without RT) is suitable. }\end{array}$ & $49 \%$ & $16 \%$ & $37 \%$ & Rejected \\
\hline $\begin{array}{l}\text { 44. For a premenopausal patient with luminal B-like (HER2-negative) tumor who had } \\
\text { CPR after NST, giving extended chemotherapy only with any relevant regimen (with } \\
\text { or without RT) is suitable. }\end{array}$ & $55 \%$ & $14 \%$ & $31 \%$ & Rejected \\
\hline $\begin{array}{l}\text { 45. For a postmenopausal patient with luminal B-like (HER2-negative) tumor who } \\
\text { had CPR after NST, giving endocrine treatment only with relevant regimen (with or } \\
\text { without RT) is suitable. }\end{array}$ & $25 \%$ & $30 \%$ & $45 \%$ & Rejecteo \\
\hline $\begin{array}{l}\text { 46. For a postmenopausal patient with luminal B-like (HER2-negative) tumor who } \\
\text { had CPR after NST, giving extended chemotherapy with relevant regimen (with or } \\
\text { without RT) is suitable. }\end{array}$ & $50 \%$ & $28 \%$ & $22 \%$ & Rejecteo \\
\hline
\end{tabular}

\section{DISCUSSION}

Current national/regional consensus has provided that NST may be given to most of those node-negative early stage $\mathrm{BC}$ patients, regardless of age, if up-front surgical therapy is not feasible. All recommendations were based on the assumption that a surgical procedure would not be performed temporarily due to restrictions under the COVID-19 pandemic conditions. Options included CT for patients with triple negative tumor, combination of anti-HER2 treatment and CT for those with HER2-positive tumor and ET for those with luminal A-like tumor. Moreover, there was an agreement among the panelists to administer neoadjuvant ET to patients with luminal A-like tumor with limited nodal involvement. All options were recommended temporarily for a period of 4 to 6 months until the outbreak subsided.

The panel also endorsed extension of systemic treatments in certain subgroups of patients who received and responded well to NST. Continuation of anti-HER2 treatment for postmenopausal patients with HER2-positive/HR-negative tumor, add-on ET with continued antiHER2 treatment for all patients with HER2-positive/HR-positive tumor and ET alone for all patients with luminal B-like tumor were regarded as acceptable alternatives to surgery under the COVID-19 outbreak circumstances, provided that there was CCR to the given NST.

Severity of the symptoms related to COVID-19 infection depends mainly on the immune condition of the host. There is clinical data suggesting that surgery may exacerbate infectious complications in critically ill patients due to impaired immune functions or augmented cytokine response, limiting surgical procedures in recently diagnosed patients (15). Although, cancer inherently creates an immune compromised environment and $\mathrm{CT}$ may render a patient more vulnerable to infection due to a temporary decrease in lymphocyte and neutrophil counts, decision of administering systemic therapy requires a personalized approach with a detailed risk-to-benefit evaluation (16). Until this date, there was no recommendation to forgo curative $\mathrm{CT}$ for patients who are otherwise in good health without any comorbid conditions that may place the patient at high risk for COVID-19-related complications. Despite statements issued by numerous oncology societies and health authorities, clear-cut recommendations cannot be made given the lack of high-quality evidence-based guidelines valid for circumstances such as the COVID-19 outbreak that we currently face $(17,18)$. Therefore, we planned to perform a consensus which would provide guidance on the management of $\mathrm{BC}$ patients when standard surgical practice options are suspended.

We used the Delphi method with Likert scale to implement the procedure electronically in order to expedite data retrieval. Although the Delphi method has been previously described as a practical, easy and user-friendly technique, there exists some limitations such as relative inaccuracy of the drafted statements and inability to integrate panelists' comments into the procedure. Furthermore, grading with 9-point in Likert scale was also criticized as it may be found confusing by the panelists (19-21).

We designated panelists through strict criteria in order to maintain a high profile of experts for the consensus. Only those breast surgeons and medical oncologists who have a special interest in breast oncology with better knowledge, skills, judgements 
and a wider range of experience were nominated as panelists. Experts were chosen from different regions of Turkey to ensure nation-wide coverage. We invited only surgeons and medical oncologists since RT was included as an optional choice in the queries to prevent confusion among panelists. Despite the seemingly high proportion of surgeons among the panelists, the actual number of both group of physicians in Turkey reflects a similar distribution (1 to 5). One of the limitations of the consensus was the low voting rates at both rounds. Although, quorum was attained at both rounds, attendance rates were not satisfactorily high. However, the clinical experience of each panelist who attended the consensus was above satisfactory.

We chose case scenarios which we believed to have reflected the real world. Case scenarios included patients in whom surgery was regarded to be the standard-of-care treatment according to evidence-based guidelines. We identified early stage patients who were normally candidates for up-front surgery or those with early or locally-advanced disease who completed their NST to be considered for this consensus. We stratified cases according to their menopausal state, molecular cancer subtype and level of response to NST, where appropriate.

Due to the common instructions of the Delphi method, some recommendations were rejected although absolute majority revealed otherwise, which was because the votes exceeded a priori decided threshold for rejection (25\%) (22). Ten statements were rejected because the number of votes exceeded the rejection threshold even though the majority held a decision favoring the endorsement but did not reach the threshold for it (75\%). Although we limited the scenarios in strict condition of which surgery could not be performed, in half of the scenarios, the panel did not provide a non-surgical alternative. Therefore, there are certain conditions which remained uncertain for a given patient. For these cases, the absolute voting percentage result would provide clinicians guidance on management in less than ideal conditions. For these scenarios, crude results with agreement exceeding half of the votes may assist clinicians to make informed decisions. Therefore, even so, some would prefer to consider absolute majority when choosing a management modality for patients with those scenarios. For example, despite rejection by a quarter of the voters, the continuation of HER2 blockade in premenopausal patients with HER2-positive/ HR-negative tumor who had CCR after NST would be the preferred treatment approach as absolute majority with $55 \%$ of the votes favored this type of option.

There are also some statements, which at the first round seemed to be rejected. However, when considering the comments written and provided by the majority of the panelists, an alternative non-surgical treatment would be supported if the statement was re-written accordingly. This was observed in patients with node-positive luminal A-like tumor for whom panel- ists made comments favoring neoadjuvant $\mathrm{CT}$. In addition, for patients with node-negative luminal B-like tumor, the majority expressed their concern for a single type of treatment instead of up-front surgery. Comments revealed that a combination of ET and $\mathrm{CT}$ should be preferred. Therefore, although all given statements seemed to be rejected, the panel agreed to provide a non-surgical option for these particular patients (Table 2).

However, after the voting of two rounds, there were scenarios left with no alternative option to replace surgery. All recommendations for patients with triple negative tumor, regardless of menopausal status, after NST were rejected. The panel rejected both options including extended CT or no systemic treatment with or without RT for these patients. Furthermore, for all patients with HER2-positive tumor, regardless of the menopausal status, who did not have CCR after NST, the panelists rejected all non-surgical recommendations including continuation of HER2 blockade with or without extended CT. Again, for all patients with luminal B-like tumor with clinical partial response (CPR) to NST, panelists did not endorse any of the non-surgical alternative treatment options limited to ET or extended CT alone. However, due to the missing treatment alternatives for cases with HER2-positive/HR-positive as well as with luminal B-like tumors who had CPR after NST, voting might have resulted inconclusive. For both pre and postmenopausal patients, we missed to integrate combination treatments in the statements, such as extended CT along with both antiHER2 blockade and ET for patients with HER2-positive/HR-positive tumor and combination of extended CT and ET for those with luminal-B like tumor. However, the panelist comments on these scenarios were not significant enough to raise a necessity for any revision accordingly.

Although our consensus results provided some guidance for daily practice during the outbreak, it should be highlighted that the results discussed here are not supported by high-level evidence, but should be acknowledged within the context of expert opinion. We did not name any specific agents regarding CT, ET and HER2 blockade as options to be voted. Therefore, the final decision on how to manage those patents is left at the physicians' discretion in daily practice. Furthermore, we did not ask the panelists' opinion on RT choices for any of the given scenarios. Nevertheless, recently an international guideline was published for RT in breast cancer patients during the COVID-19 outbreak (23). Therefore, recommendations regarding RT should be individualized for each scenario discussed in this consensus report. A multidisciplinary approach is crucial to determine practical and relevant solutions for each given patient.

Conceptually, the results yielded by the current consensus can be considered to have validity as the intended inferences or interpretations remain generally consistent with an inherent 
Table 2. Recommendation box (Summary of the endorsed statements)

"Below recommendations are endorsed only under the temporary conditions where surgical treatment is not feasible due to extraordinary circumstances and are valid until due surgical treatment is available."

Strong endorsement (with over-threshold agreement $\geq 75 \%$ )

- $\quad$ For a new patient (regardless of menopausal stage) with stage T1N0M0, grade 3, triple negative tumor (HER2-negative/HR-negative), giving NST (4-6 months) with any relevant regimen* is suitable.

- $\quad$ For a new patient (regardless of menopausal stage) with stage T1NOMO, grade 3, HER2-positive (regardless of HR expression level) tumor, giving NST (4-6 months) with any relevant regimen (including anti HER2 treatment) is suitable.

- $\quad$ For a new patient (regardless of menopausal stage) with stage T1N0M0, grade 1, luminal A-like (HER2-negative/HR-highly positive/ Ki67 < 15\%) tumor, giving neoadjuvant endocrine treatment alone (4-6 months) with any relevant regimen is suitable.

- $\quad$ For a new postmenopausal patient with stage T1-2N1M0, grade 2, luminal A-like (HER2-negative/HR-highly positive/Ki67 < 15\%) tumor, giving neoadjuvant endocrine treatment alone (4-6 months) with any relevant regimen is suitable.

- $\quad$ For a postmenopausal patient with HER2-positive/HR-negative tumor who had clinical complete response after NST, continuing with antiHER2 treatment alone with any relevant regimen (with/without RT) is suitable.

- $\quad$ For a patient (regardless of menopausal stage) with HER2-positive/HR-positive tumor who had clinical complete response after NST, continuing with combined anti-HER2 and endocrine treatments (with/without RT) with any relevant regimen is suitable.

- $\quad$ For a patient (regardless of menopausal stage) with luminal B-like (HER2-negative/HR-low positive) tumor who had clinical complete response after NST, continuing with endocrine treatment only (with/without RT) with any relevant regimen is suitable.

Endorsed (after statement revision with panelists' comments)

- $\quad$ For a new pre-menopausal patient with stage T1-2N1M0, grade 2, luminal A-like (HER2-negative/HR-highly positive/ Ki67 < 15\%) tumor, giving neoadjuvant chemotherapy alone (4-6 months) with any relevant regimen is suitable.

- $\quad$ For a new patient (regardless of menopausal stage) with stage T1N0M0, grade 2, luminal B-like (HER2-negative/HR-low positive/Ki67 > 15\%) tumor, giving combined neoadjuvant chemotherapy and endocrine treatment (4-6 months) with any relevant regimen is suitable.

Weak endorsement (only by absolute majority $>50 \%$ with rejection rate $\geq 25 \%$ )

- $\quad$ For a pre-menopausal patient with HER2-positive/HR-negative tumor who had clinical complete response after NST, continuing with antiHER2 treatment alone (with/without RT) with any relevant regimen is suitable.

HR: Hormone receptor, NST: Neoadjuvant systemic treatment, RT: Radiation treatment.

* Relevant regimen: Single or combined systemic treatments previously recommended for similar subgroup of patients in neoadjuvant or adjuvant settings.

logical perspective. We think that the results of this consensus would provide guidance for clinicians dealing with BC patients under compelling conditions such as the COVID-19 outbreak, when surgery is not deemed to be feasible. It should be noted that the results discussed herein should not be used to refute surgery in an appropriate clinical setting under normal conditions where no potential contraindication exists.

Affiliations: MNA; Atatürk University School of Medicine, Department of General Surgery, Erzurum, EA; MAMER Clinic, Breast Surgery Unit, Bursa, KA; Atatürk Training and Research Hospital, Department of General Surgery, Izmir, SB, AIF and AK; Okan University School of Medicine, Department of General Surgery, Istanbul, BB; Hitit University School of Medicine, Department of General Surgery, Corum, NC, Al and VO; Istanbul University Istanbul School of Medicine, Depart ment of General Surgery, Istanbul, NZC; Kocaeli University School of Medicine Department of General Surgery, Kocaeli, HSC and SSG; Akdeniz University School of Medicine, Department of Medical Oncology, Antalya, MC; Murat Calikapan Breast Clinic, Bursa, BC; Sisli Etfal Training and Research Hospital, Department of General Surgery, Istanbul, Orhan Demircan; Acibadem Adana Hospital, Department of General Surgery, Adana, LD; Dr. Abdurrahman Yurtaslan Oncology Training and Research Hospital, Department of General Surgery, ME; Tepecik Training and Research Hospital, Department of General Surgery, Izmir, OE and OS; MAA Acibadem University School of Medicine, Department of Medical Oncology, Istanbul, SE; Ankara Training and Research Hospital, Department of General Surgery, Ankara, EG; Cerrahpasa School of Medicine, Department of
General Surgery, Istanbul, SG; Dicle University School of Medicine, Department of Medical Oncology, Diyarbakir, SG; Semih Gorgulu Breast and Endocrine Surgery Clinic, Ankara, MAG; Gulhane School of Medicine, Department of General Surgery, Ankara, SG; Okmeydani Cemil Tascioglu Training and Research Hospital, Department of General Surgery, Istanbul, GG; Haydarpasa Numune Training and Research Hospital, Department of General Surgery, Istanbul, VH; Medline Adana Hospital, Department of Medical Oncology, Adana, Hacettepe University School of Medicine, Department of Medical Oncology, Ankara, HKa; Istanbul University Institute of Oncology, Department of Surgical Oncology, Istanbul, SK; Hacettepe University School of Medicine, Department of Medical Oncology, Ankara, BK; Sakarya University School of Medicine, Department of General Surgery, Adapazari, HKo; Konya Training and Research Hospital, Department of General Surgery, Konya, FK; Baskent University School of Medicine, Department of Medical Oncology, Adana, BK, AKP and NO; Ondokuz Mayis University School of Medicine, Department of General Surgery, Samsun, SP; Cukurova University School of Medicine, Department of Medical Oncology, Adana, SO; Serdar Ozbas Breast and Endocrine Surgery Clinic, Ankara, GS; Cukurova University School of Medicine, Department of General Surgery, Adana, AS; Acibadem Altunizade Hospital, Breast Surgery Unit, Istanbul, MANS; Yildirim Beyazit University School of Medicine, Department of Medical Oncology, CT; Baskent University School of Medicine, Department of General Surgery, Istanbul, MUU; Marmara University School of Medicine, Department of General Surgery, Istanbul, HU; Acibadem Kadıkoy Hospital, Department of General Surgery, Istanbul, LY; Ege University School of Medicine, Department of General Surgery, Izmir, CY; Istanbul Oncology Hospital, Breast Surgery Unit, Istanbul, IY; Ondokuz Mayis University School of Medicine, Department of Medical Oncology, Samsun. 
Ethics Committee Approval: Not relevant.

Peer-review: Externally peer-reviewed.

Author Contributions: Concept - A.S., B.M.G., G.K.C., G.B., B.O., Y.E.; Design A.S., B.M.G., S.O.G.; Supervision - A.S., B.M.G., I.C., G.B.; Resource - A.S., B.M.G., S.O.G.; Materials - A.S., B.M.G., I.C.; Data Collection and/or Processing - A.S., B.M.G., G.K.C., S.O.G., Task Force Specialists; Analysis and Interpretation - A.S., B.M.G., I.C., G.B., B.O., Y.E.; Literature Review - A.S., B.M.G., G.K.C., S.O.G.; Writing Manuscript - A.S., B.M.G., G.B., B.O., Y.E.; Critical Reviews - A.S., B.M.G., I.C., G.K.C., B.O., Y.E.

Conflict of Interest: The authors declared no conflict of interest

Financial Disclosure: The authors declared that this study has received no financial support.

\section{REFERENCES}

1. COVID-19 dashboard by the center for systems science and engineering (CSSE) at Johns Hopkins [cited 2020 Apr 14], available from: https://coronavirus.jhu.edu/map.html. [CrossRef]

2. Zarzaur BL, Stahl CC, Greenberg JA, Savage SA, Minter RM. Blueprint for restructuring a department of surgery in concert with the health care system during a pandemic: the University of Wisconsin experience. JAMA Surg 2020 (published online April 14, 2020) doi: 10.1001/ jamasurg.2020.1386. [CrossRef]

3. Society of Surgical Oncology. Resource for management options of breast cancer during COVID-19 [cited $2020 \mathrm{Apr} 14$ ], available from: https://www.surgonc.org/wp-content/uploads/2020/03/Breast-Resource-during-COVID-19-3.30.20.pdf. [CrossRef]

4. American College of Surgeons. COVID-19: Guidance for triage of nonemergent surgical procedures [cited $2020 \mathrm{Apr}$ 14], available from: https://www.facs.org/covid-19/clinical-guidance/triage [CrossRef]

5. McBride KE, Brown KGM, Fisher OM, Steffens D, Yeo DA, Koh CE, et al. Impact of the COVID-19 pandemic on surgical services: early experiences at a nominated COVID-19 centre. ANZ J Surg 2020 (published online April 7, 2020) doi: 10.1111/ans.15900. [CrossRef]

6. Besnier E, Tuech JJ, Schwarz L. We asked the experts: Covid-19 outbreak: is there still a place for scheduled surgery? "Reflection from pathophysiological data." World J Surg 2020 (published online April 3, 2020) doi: 10.1007/s00268-020-05501-6. [CrossRef]

7. Tuech JJ, Gangloff A, Di Fiore F, Michel P, Brigand C, Slim K, et al. Strategy for the practice of digestive surgery and surgical oncology in COVID-19 epidemic. J Visc Surg 2020 (published online March 31, 2020) doi: 10.1016/j.jviscsurg.2020.03.008. [CrossRef]

8. Zhou F, Yu T, Du R, Fan G, Liu Y, Liu Z, et al. Clinical course and risk factors for mortality of adult inpatients with COVID-19 in Wuhan, China: a retrospective cohort study. Lancet 2020;395(10229):1054-62. doi: 10.1016/50140-6736(20)30566-3. [CrossRef]

9. Liang W, Guan W, Chen R, Wang W, Li J, Xu K, et al. Cancer patients in SARS-CoV-2 infection: a nationwide analysis in China. Lancet Oncol 2020;21(3):335-7. doi: 10.1016/51470-2045(20)30096-6. [CrossRef]
10. Dietz JR, Moram MS, IsakoffSJ, et al. Recommendations for prioritization, treatment and triage of breast cancer patients during the COVID-19 pandemic. [cited 2020 Apr 15] available from:https://www.facs.org/-/ media/files/quality-programs/napbc/asbrs_napbc_coc_nccn_acr_ bc_covid_consortium_recommendations.ashx. [CrossRef]

11. Karadeniz-Çakmak G, Özmen V. Sars-CoV-2 (COVID-19) outbreak and breast cancer surgery in Turkey. Eur J Breast Health 2020;16(2):83-5. doi: 10.5152/ejbh.2020.300320. [CrossRef]

12. Al-Shamsi HO, Alhazzani W, Alhuraiji A, Coomes EA, Chemaly RF, Almuhanna $M$, et al. A practical approach to the management of cancer patients during the novel Coronavirus disease 2019 (COVID-19) pandemic: an International Collaborative Group. Oncologist 2020 (published online April 3, 2020) doi: 10.1634/theoncologist.2020-0213. [CrossRef]

13. Ueda M, Martins R, Hendrie PC, McDonnell T, Crews JR, Wong TL, et al. Managing cancer care during the COVID-19 pandemic: agility and collaboration toward a common goal. J Natl Compr Canc Netw 2020:1-4. doi: 10.6004/jnccn.2020.7560. [CrossRef]

14. Armon K. Consensus processes. In: Bowker R, Lakhanpaul M, Atkinson M, Armon K, MacFaul R, Stephenson T (eds). How to Write a Guideline: From Start to Finish. Toronto: Churchill-Livingstone Elsevier, 2008:77-84. [CrossRef]

15. Kawasaki T, Sata T. Perioperative innate immunity and its modulatiOn. J UOEH 2011;33:123-37. [CrossRef]

16. Barnes RA. Infection in cancer and transplantation. Medicine (Abingdon) 2013;41:624-7. [CrossRef]

17. American Society of Medical Oncology. New guidance released for oncology community on allocation of limited resources during COVID-19 pandemic [cited $2020 \mathrm{Apr} 17$ ] available from: asco.org/aboutasco/press-center/news-releases/new-guidance-released-oncologycommunity-allocation-limited. [CrossRef]

18. ESMO management and treatment adapted recommendations in the COVID-19 era: Breast cancer. [cited 2020 Apr 17] available from: https://www.esmo.org/guidelines/cancer-patient-managementduring-the-covid-19-pandemic/breast-cancer-in-the-covid-19-era. [CrossRef]

19. Jairath N, Weinstein J. The Delphi methodology (Part one): A useful administrative approach. Can J Nurs Adm 1994;7:29-42. [CrossRef]

20. Duffield C. The Delphi technique: a comparison of results obtained using two expert panels. Int J Nurs Studies 1993;30:227-37. [CrossRef]

21. Powell C. The Delphi technique: myths and realities. J Adv Nurs 2003:41:376-82. [CrossRef]

22. Armon K. The Delphi consensus process. In: Bowker R, Lakhanpaul M, Atkinson M, Armon K, MacFaul R, Stephenson T (eds). How to Write a Guideline: From Start to Finish. Toronto: Churchill-Livingstone Elsevier, 2008:85-96. [CrossRef]

23. Coles CE, Aristei C, Bliss J, Boersma L, Brunt AM, Chatterjee S, et al. International guidelines on radiation therapy for breast cancer during the COVID-19 pandemic. Clin Oncol (R Coll Radiol) 2020;32:279-81. doi: 10.1016/j.clon.2020.03.006. [CrossRef] 


\title{
ORIJINAL ÇALIŞMA-ÖZET
}

Turk J Surg 2020; 36 (2): 147-163

\section{COVID-19 salgınına bağlı olağanüstü durumlarda meme kanseri yönetiminde Türkiye ulusal konsensüsü}

\author{
Atakan Sezer ${ }^{1,2}$, İran Cicin ${ }^{3}$, Güldeniz Karadeniz Çakmak ${ }^{1,4}$, Sibel Özkan Gürdal ${ }^{1,5}$, Gül Başaran ${ }^{1,6}$, Başak Oyan ${ }^{6}$, Yeşim Eralp ${ }^{6}$, \\ Bahadır M. Güllüoğlu ${ }^{1,7}$, Türk Ulusal Meme Onkolojisi Uzmanları COVID-19 Görev Gücü ${ }^{8}$ \\ ${ }^{1}$ SENATURK Senoloji Akademi-Türkiye, İstanbul, Türkiye \\ ${ }^{2}$ Trakya Üniversitesi Tıp Fakültesi, Genel Cerrahi Anabilim Dalı, Edirne, Türkiye \\ ${ }^{3}$ Trakya Üniversitesi Tıp Fakültesi, Medikal Onkoloji Bilim Dalı, Edirne, Türkiye \\ ${ }^{4}$ Zonguldak Bülent Ecevit Üniversitesi Tıp Fakültesi, Genel Cerrahi Anabilim Dalı, Zonguldak, Türkiye \\ ${ }^{5}$ Namık Kemal Üniversitesi Tıp Fakültesi, Genel Cerrahi Anabilim Dalı, Tekirdağ, Türkiye \\ ${ }^{6}$ MAA Acıbadem Üniversitesi Tıp Fakültesi, Medikal Onkoloji Bilim Dalı, İstanbul, Türkiye \\ ${ }^{7}$ Marmara Üniversitesi Tıp Fakültesi, Genel Cerrahi Anabilim Dalı, İstanbul, Türkiye \\ ${ }^{8}$ Türk Ulusal Meme Onkolojisi Uzmanları COVID-19 Görev Gücü: Müfide Nuran Akçay, Erol Aksaz, Kemal Atahan, Semih Baskan, Betül Bozkurt, Neslihan \\ Cabioğlu, N. Zafer Cantürk, Hasan Şenol Coşkun, Murat Çalıkapan, Bülent Çitgez, Orhan Demircan, Lütfi Doğan, Mustafa Emiroğlu, Özlem Er, Serap \\ Erel, Ali Illker Filiz, Ertuğrul Gazioğlu, Sadullah Girgin, Sema Sezgin Göksu, Semih Görgülü, Mehmet Ali Gülçelik, Semra Günay, Günay Gürleyik, Veysel \\ Haksöyler, Abdullah Ĭğci, Hasan Karanlık, Abut Kebudi, Saadettin Kilıçkap, Belma Koçer, Hande Köksal, Fatih Köse, Bekir Kuru, Semra Paydaş, Ayfer \\ Kamalı Polat, Serdar Özbaş, Necati Özen, Vahit Özmen, Gürhan Sakman, Aykut Soyder, Özlem Sönmez, Mehmet Ali Nahit Şendur, Cemalettin Topuzlu, \\ M. Ümit Uğurlu, Hilal Ünal, Levent Yeniay, Cem Yılmaz, Idris Yücel.
}

\section{ÖZET}

Giriş ve Amaç: Kanser tedavisi çeşitli nedenlerden ötürü COVID-19 salgınından büyük ölçüde etkilenmiştir. Bu noktada en büyük endişelerden biri meme kanseri hastalarının cerrahi tedavilerinin gecikmesine eğilimdir. Salgın klinisyenleri cerrahinin uygun ve güvenli olduğu düşünülene kadar alternatif tedaviler bulmaya yönlendirmektedir. Bu çalışmada, Türkiye'de COVID-19 salgını sırasında meme kanseri tedavisi için uzman görüşü temelli bir rehber sunmayı amaçlayan konsensüs prosedürünün sonuçlarını bildiriyoruz.

Gereç ve Yöntem: Meme kanseri tedavisinde gerekli bilgi ve tecrübeye sahip 51 cerrah ve tıbbi onkoloğun iki turda oyladığı dokuz ölçekli Likert Skalalı Delphi metodunu kullandık. Oylama elektronik ortamda anket formatlı form ile gerçekleştirildi.

Bulgular: Yirmi sekiz farklı olgu senaryosuna ait toplamda 46 öneri oylandı. İlk turda 37 öneri üzerinde onay veya ret şeklinde konsensüs sağlandı. Dokuz öneri konsensüs için yeterli karar eşiğini geçemediğinden ikinci tura aktarıldı. İki turun sonunda 14 olgu senaryosu için bir öneri kabul edilerek onaylandı. Geriye kalan 14 olgu senaryosuna ait 32 öneri ise reddedildi.

Sonuç: Gereken cerrahi tedavi için uygun şartlar sağlanıncaya kadar nod negatif küçük çaplı üçlü negatif, HER-2 pozitif ve Luminal-A tümörlerde neoadjuvan sistemik tedavinin uygulanması konusunda genel konsensüs sağlandı. Panelistler ayrıca neoadjuvan sistemik tedavi sonrası klinik tam yanıt veren HER-2 pozitif ve Luminal B tümörlerde de sistemik tedavinin uzatılması konusunda konsensüse ulaştı.

Anahtar Kelimeler: COVID-19, meme kanseri, meme cerrahisi, konsensüs

Doi: $10.5578 /$ turkjsurg.4815 